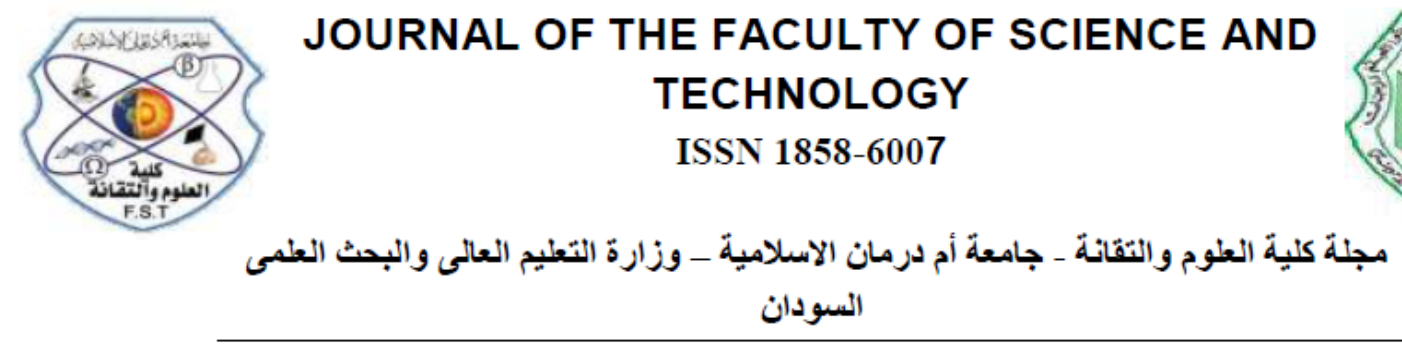

Research article

\title{
The extent of trace metals pollution in fruit dates palm and associated soil of Zilfi Province, Saudi Arabia \\ Nawal M.Suleman*
}

\author{
* Department of chemistry, Faculty of Education, Khartoum University, Omdurman, P.O.box 406, Sudan \\ e-mail:nawal.mahgoub@uofk.edu
}

\begin{abstract}
Fruits and vegetables are edible plant products that are good for health, some trace elements concentration $(\mathrm{Cu}, \mathrm{Hg}, \mathrm{Mn}, \mathrm{Ni}, \mathrm{Pb}$, and $\mathrm{V})$ which may be found as pollutants in fruit dates palm and agricultural soils at Zilfi Province were determined by using ICP-MS spectrophotometer. The concentrations in $\mathrm{mg} / \mathrm{kg}$ of the elements under study in agricultural soil were found ranged as follows: $\mathrm{Cu}(5.8-16.6), \mathrm{Hg}(1.4-3), \mathrm{Mn}$ (55.9-506.9), $\mathrm{Ni}(3.6-48.1), \mathrm{Pb}(7.2-184.4), \mathrm{V}(82.6-136.5)$. Four samples (5,6.10 and 11) have been contaminated with lead when we compare these values with the maximum allowable limits for $\mathrm{WHO}$ for $\mathrm{Pb}(100 \mathrm{mg} / \mathrm{kg})$. The concentrations in $\mathrm{mg} / \mathrm{kg}$ of the elements under study in date palm fruit were found, ranged as follows: $\mathrm{Cu}$ (1.8-5.3), $\mathrm{Hg}(0.17-1.4), \mathrm{Mn}$ (2.4-12.6), $\mathrm{Ni}(0.75-7.6)$, $\mathrm{Pb}$ (1.2-24.7), and V (11.6-17.3). All date samples were found to be contaminated with Mn element except sample (5). The concentrations of Nickel and Lead in all date palm fruits samples show high contamination compared to WHO/FAO limits for these elements. There have been highly pollution of soil and dates grown in the Zilfi Province elements by lead, but the pollution by mercury is only found in dates samples.
\end{abstract}

Keywords: Date Palm, Trace Elements, Inductively Coupled Plasma, Agricultural Soil, Zilfi.

\section{INTRODUCTION}

Fruits are an integral part of the human diet as they supply vitamins and minerals, which are important nutrients essential for human health [Mumzuroglu et.al 2003]. The date palm (Phoenix dactylifera L., family Arecaceae) is one of the oldest cultivated trees in arid and semi-arid regions. Saudi Arabia is the world's second-largest producer of dates; its date production amounted to 1.07 million tons. Zilli province with considerable agricultural potential in soil fertility and abundant water and famous for its abundant vegetation and in the introduction to that date as the spread of Palm, in
Al Zilfi currently over 8000 total farm output of dates over 7360 tones and more than 2 million palm trees. Emission of heavy metals from the industries and vehicles may result in the deposition of such metals on the surface of the fruits and vegetables. Since, these heavy metals might seriously damage human health e.g., decrease in immunological defense, neurological disorders, intrauterine growth retardation, For these reasons we want to determine some trace elements as pollutants in fruit dates palm and agricultural soils at Zilfi Province by using ICP-MS spectrophotometer which represents an analytical tool with high precision. 
Dates are very rich in nutritive components, [Alshahib and Marshal 2003]. Trace elements like Pb, $\mathrm{Cd}, \mathrm{Cr}$, and $\mathrm{Ni}$, can deposit in various body organs which possess a great threat to human health [Singh et.al 2004], [ Chen 2005].Crops grown on soils irrigated with wastewater can accumulate a significant amount of heavy metals in different tissues [Khairia et.al 2004],[ Chojnachaet.al 2005 ],[ Muchuwetiet.al 2006] Since these heavy metals might seriously damage human health [Arora et .al 2008].Hence, regular survey and monitoring programs of heavy metal contamination in foodstuff were mainly centered for decades in developed countries[Jorhem and Sundstrom 1993],[ Milacic, and Kralj 2003)[ Saracoglu et.al 2004]. Evaluation of newly date palm cultivar irrigated by both treated wastewater and Nile water was studied [Abu-Rekab and El-Kerdany 2009]. Concentrations of $\mathrm{Cu}, \mathrm{Zn}, \mathrm{Pb}, \mathrm{Cr}, \mathrm{Cd}, \mathrm{Fe}$, and $\mathrm{Ni}$ have been estimated in soils and vegetables grown in and around an industrial area of Bangladesh[Uddin 2010] Leaves of roadside plants as bioindicator of traffic-related lead pollution during different seasons in Sargodha, Pakistan have been studied[Naveed et.al 2010 ]. Antioxidants of the heart of date palm from three Saudi cultivars was studied [Trabzuni et.al 2014], also mineral ion content of date palm [Ahmed and Ahmed (2004], [Mohammadzai et.al 2010] was determined at different places. Many studies have been carried out dealing with trace elements analysis [Gboori and Krepl 2010],[Mohebi 2010], [Williams and Pillay 2011],[ Marzouk and Kassem 2011],[Yassine et. al 2012],[ Aleksand 2008],[ Babiker et.al 2013], [ Ogbonnaa et.al 2013].

\section{MATERIALS AND METHODS}

\subsection{Instrumentation}

The analytical determination of trace metals was carried out by ICP-MS (Inductively Coupled Plasma-Mass Spectrometer): ELAN 9000 (Perkin Elmer Sciex Instrument, Concord, Ontario, Canada), see Table (1) highlights the operating conditions of the instruments used in this study. Germany. High purity water obtained from a Millipore Milli-Q water purification system was used throughout the work.

\subsection{Calibration}

The ICP-MS calibration was carried out by external calibration with the blank solution and three working standard solutions (10, 20 and 30 $\mu \mathrm{g} / \mathrm{L}$ ) for all elements, starting from a $1000 \mathrm{mg} / \mathrm{L}$ single standard solutions for ICP-MS (Aristar grade, BDH laboratory supplies, England for the trace elements.

Table 1. Conditions of ELAN 9000 ICP-MS

\begin{tabular}{|c|c|}
\hline RF power & $1250 \mathrm{~W}$ \\
\hline Nebulizer gas flow & $0.92 \mathrm{~L} / \mathrm{min}$ \\
\hline Lens Voltage & $9.25 \mathrm{~V}$ \\
\hline Analog Stage voltage & $-1762.5 \mathrm{~V}$ \\
\hline Pulse Stage Voltage & $1050 \mathrm{~V}$ \\
\hline Number of replicates & 3 \\
\hline Reading / Replicates & 20 \\
\hline Scan Mode & Peak Hopping \\
\hline Dwell Time & 40 mins \\
\hline
\end{tabular}

It is very important to maintain these margins. They are necessary to put conference information and page number for the proceedings.

\subsection{Sample Collection and Preparation}

The area of study, the date palm farms found at Zilfi Province, was surfed during September 2013 taking 11 samples of soil from these farms randomly(see map). Also, 11 samples of date palm fruit (fully ripe, stage of Tamer) would be collected from the same farms. The date samples were divided into two groups. The first group was washed with deionized water to clean dust and deposited substances on fruit for 10 min while the second group was not washed. All samples airdried and then oven-dried at $70^{\circ} \mathrm{C}$ for $48 \mathrm{~h}$ to achieve constant mass, milled and sieved through a 35 mesh screen. $1 \mathrm{~g}$ milled powder of each sample was weighed and after combusting in electrical furnace, were digested with $10 \mathrm{ml} 2 \mathrm{~N} \mathrm{HCl}$. The resulting digest was not clear, so it was filtered through Whatman filtered paper no.42.The filtered digest was transferred to a $50 \mathrm{ml}$ volumetric flask and made up to mark using deionized water. A blank digest was carried out in the same way. The trace elements $(\mathrm{Cu}, \mathrm{Hg}, \mathrm{Mn}, \mathrm{Ni}, \mathrm{Pb}$, and $\mathrm{V})$ concentrations were determined by ICP-MS (Inductively Coupled Plasma-Mass Spectrometer) [Ataabadi and Najafi 2012]. 


\subsection{Coordinates Measuring}

The coordinates of the farms have been measured (Fig. 1.) using Germain( German Nuvi 1410 which was made in Taiwan)

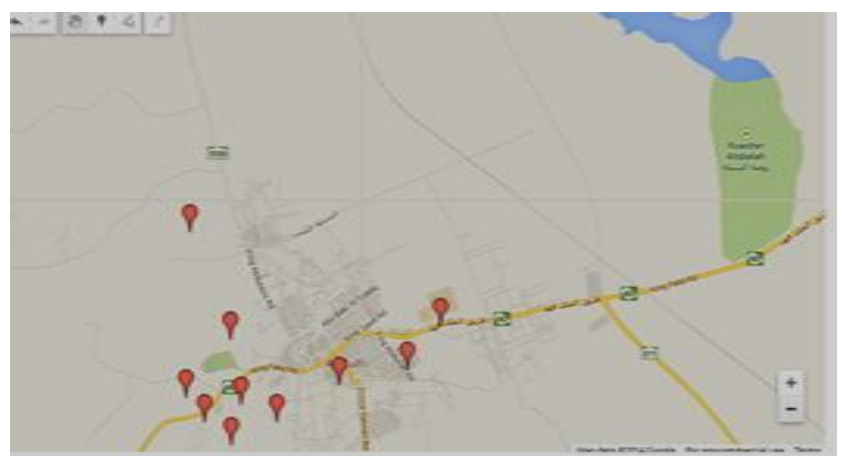

Fig. 1. Date palm farms understudy at Zilfi

\section{RESULT AND DISCUSSION}

All calibration graphs are linear in the selected range of each element.The correlation factors $\left(\mathrm{R}^{2}\right)$ range from 0.9985-0. 99999 for most of the elements in these investigations. Good precision values were obtained.The results have been reviewed in Tables (2-3) and Figs. (2-7).

\subsection{Soils}

The concentrations of the elements under study in agricultural soil samples in $\mathrm{mg} / \mathrm{kg}$ have found as follows: $\mathrm{Cu}$ (5.8-16.6), $\mathrm{Hg}$ (1.4-3), $\mathrm{Mn}$ (55.9506.9), $\mathrm{Ni}$ (3.6-48.1), Pb (7.2-184.4), V (82.6136.5). When comparing the maximum concentrations of these metals with allowable limits for WHO: $\mathrm{Cu}$ (100), $\mathrm{Hg}$ (5) and $\mathrm{Mn}$ (2000mg/kg) [Chiroma et.al 2014], It shows that there is no pollution with these elements. This result agrees with the results of Abollino[Abollino et. al 2002.], which indicates that total $\mathrm{Cu}, \mathrm{Mn}$, and $\mathrm{Ni}$ concentrations are in the range of unpolluted soil.The amount of $\mathrm{Cu}$ in the study of the accumulation of heavy metals in agricultural soils of Mediterranean is about $65.23 \mathrm{mg} / \mathrm{kg}$ [Mico et.al 2006].

The pollution by lead was found in eight farms that have concentrations more than the values of both Saskatchewan Tier End Point Values for Soils (45 $\mathrm{mg} / \mathrm{kg}$ ), and SQGE soil quality guideline for environmental health $(70 \mathrm{mg} / \mathrm{kg})$. We can order the concentrations of lead element in soil samples as follows :sample(1),(5),(6), (7),(8), (9) (10), and(11), ,with lead concentrations in $\mathrm{mg} / \mathrm{kg}$ : (79), (184.4), (182.6), (92.4), (81.8),(59.9), (154), (131.1), respectively. Four samples (5, 6.10 and 11) have been contaminated with lead, when we compare these values

with the maximum allowable limits for $\mathrm{WHO}$ for $\mathrm{Pb}(100 \mathrm{mg} / \mathrm{kg})$, and the study of Kelepertiziz [Kelepertziz 2014] for the accumulation of heavy metals in agricultural soils of Mediterranean. Moreover among the heavy metals, $\mathrm{Pb}$ is the most immobile element and its content in soil is closely associated with clay minerals, Mn-oxides, $\mathrm{Al}$ and Fe hydroxides, and organic material [Rahman et.al 2012] and combustion of gasoline that contains tetraethyl lead as anti-knock agent [Tuzen 2003].Vanadium element concentrations in $\mathrm{mg} / \mathrm{kg}$ which are more than Saskatchewan value(86 $\mathrm{mg} / \mathrm{kg}$ ), are as follows: (136.5), (131.6), (114.4), 112.8), (110),( 100.2), (91.9), and (90.6) found in farms, (5), (6), (9), (8), (10), (11), (3), and(2) respectively. Also, we can say that soil samples (5 and 6) have $\mathrm{V}$ concentrations more the values of SQGE soil quality guideline for environmental health $(130 \mathrm{mg} / \mathrm{kg}) . \mathrm{V}$ is considered to be a toxic element in both cationic and anionic form, although the latter type has more serious side effects. In humans, the threshold for $\mathrm{V}$ toxicity is near $10 \mathrm{mg} /$ day, representing a thousandfold of the nutritional intake [Jassir et al 2005]. There is high contamination of soil sample (5) which has the maximum concentrations of $\mathrm{Pb}$, and $\mathrm{V}$. The high pollution of this farm may due to Impact on Main Street. Emission of heavy metals from the industries and vehicles may result in the deposition of such metals on the surface of the fruits and vegetables and contaminate them. Farm soil (4) which lie at inner street have maximum concentrations of the elements $(\mathrm{Mn}$, and $\mathrm{Ni})$. The maximum concentrations of $(\mathrm{Hg}$ and $\mathrm{Cu})$ were detected in the soil sample (11). The minimum concentrations of the elements $(\mathrm{Cu}, \mathrm{Mn}$, and $\mathrm{Pb})$ were found in farm soil(3), which lie away from the main streets. Farm(7) contains the minimum concentrations of (Ni). The minimum concentrations of ( $\mathrm{Hg}$ and $\mathrm{V}$ ) were found in the soil samples (4and 10) respectively. 


\subsection{Date Palm Fruits}

The concentrations of the elements under study in date palm fruit samples in $\mathrm{mg} / \mathrm{kg}$ have found as follows: $\mathrm{Cu}(1.8-5.3), \mathrm{Hg}(0.17-1.4), \mathrm{Mn}(2.4-12.6)$, $\mathrm{Ni}(0.75-7.6), \mathrm{Pb}(1.2-24.7)$, and $\mathrm{V}(11.6-17.3)$.The most contaminated date sample compared to the other samples under study was a sample (1), as it contains the maximum concentrations of the elements $(\mathrm{Cu}, \mathrm{Pb}$, and $\mathrm{V})$. The maximum concentration of $(\mathrm{Mn})$ was found in date sample (8), while those of $(\mathrm{Hg}$ and $\mathrm{Ni}$ ) are lying in samples $(4$, and 2$)$ respectively. The element $(\mathrm{Cu})$ concentrations in date fruits samples are in the same range compared to allowable WHO and EU levels concentrations, in both washed and unwashed date samples. This result agrees with the study about heavy metals content of vegetables in Romania[Nedelescu et.al 2015]. There was high pollution in date palm fruit by mercury in all samples compared with permeable limits of $\mathrm{WHO}(0.05 \mathrm{mg} / \mathrm{kg})$. The source of pollution by mercury is not the result of farmland because the mercury concentration levels have been found less than the allowable in soil. limits. $\mathrm{Hg}$ is considered as a highly toxic contaminant.The animal consumed high mercury vegetation will suffer from alopecia, neuropathy, visual and gastrointestinal disorder[Raikwar et.al 2008]. The save limit of WHO/FAO concentration of manganese element in vegetables is $(5 \mathrm{mg} / \mathrm{kg})$, when compared this limit with concentrations of $\mathrm{Mn}$ in date palm fruit found in this study.All samples are found to be contaminated with Mn element except sample (5). These values also are high than the values found in the study of Ogunkunle [Ogunkunle et.al 2014] in Nigeria. Because manganese is an essential nutrient, a certain amount must be ingested regularly to maintain health. Although the precise

requirement has not been determined, 2.5 to 5.0 milligrams per day ( $\mathrm{mg} /$ day) has been estimated to constitute an adequate and safe intake. Information regarding the carcinogenicity (ability to cause cancer) of manganese in humans or animals is not available Information regarding the carcinogenicity (ability to cause cancer) of manganese in humans or animals is not available. The concentrations of Nickel in all date palm fruits samples show high contamination compared to WHO/FAO limits for this element $(0.5-1 \mathrm{mg} / \mathrm{kg})$, and maximum permitted
[Halim 2013], limit in Turkish regulations (0.1 $0.2 \mathrm{mg} / \mathrm{kg}$ ). Natural sources of atmospheric nickel include dust from volcanic emissions and the weathering of rocks and soils. Nickel is a ubiquitous metal, which finds increasingly more applications in modern technologies. Contact with nickel compounds (both soluble and insoluble) can cause a variety of adverse effects on human health. The most important and frequent are nickel allergy in the form of contact dermatitis, lung fibrosis, cardiovascular and kidney diseases, and lung and nasal cancers[Szydłowska-Czerniak et.al 2013]. All date palm fruits sample under study shows high contamination with lead compared to WHO/FAO save limits $(0.3 \mathrm{mg} / \mathrm{kg})$. This result agrees with Mohsen and Mohsen [Mohsen and Mohsen 2013], and [Raikwar et.al 2008]. The introduction of lead into the food chain may affect human health, causing damage to the kidney and brain.

The concentrations of vanadium in fruit date samples were very high than literature concentrations in wheat, grain $(7-10 \mu \mathrm{g} / \mathrm{kg})$ indicating high pollution by this element, the reviewed topic of $\mathrm{V}$ phytotoxicity and stated that no reports are indicating its toxicity

under field conditions[Alina 2011]. Also, the study about vanadium in medical plants[Simona2009], revealed an average $\mathrm{V}$ content of $502 \mu \mathrm{g} / \mathrm{kg}$ in these plants. As general the concentrations of these elements are less in washed date samples compared to unwashed ones.

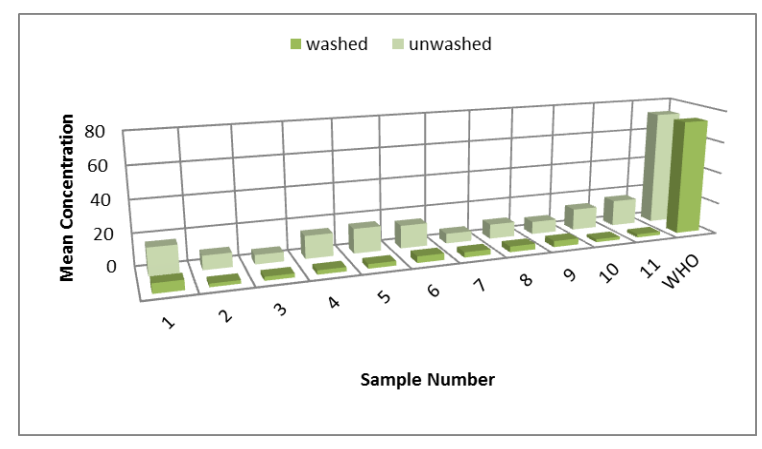

Fig. 2 Mean concentrations for copper in washed and unwashed date samples 


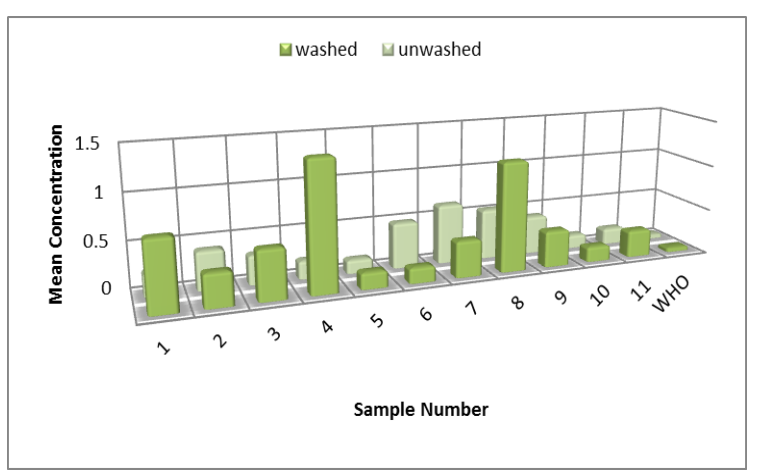

Fig. 3 Mean concentrations for mercury in washed and unwashed date samples

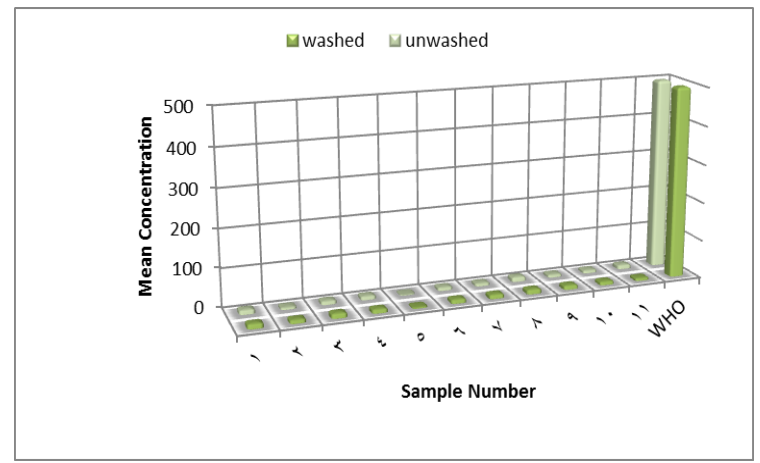

Fig. 4 Mean concentrations for manganese in washed and unwashed date samples

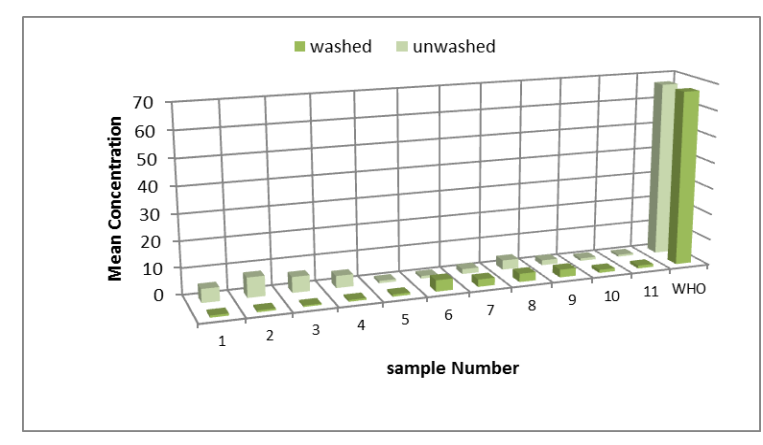

Fig. 5 Mean concentrations for nickel in washed and unwashed date samples

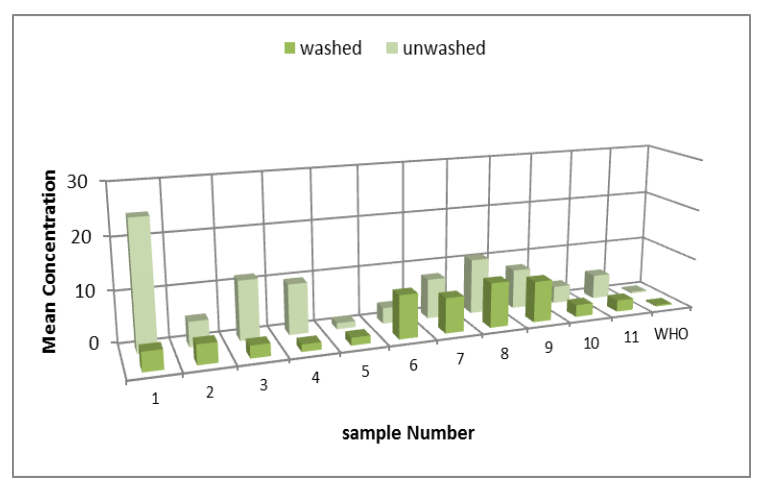

Fig. 6 Mean concentrations for lead in washed and unwashed date samples

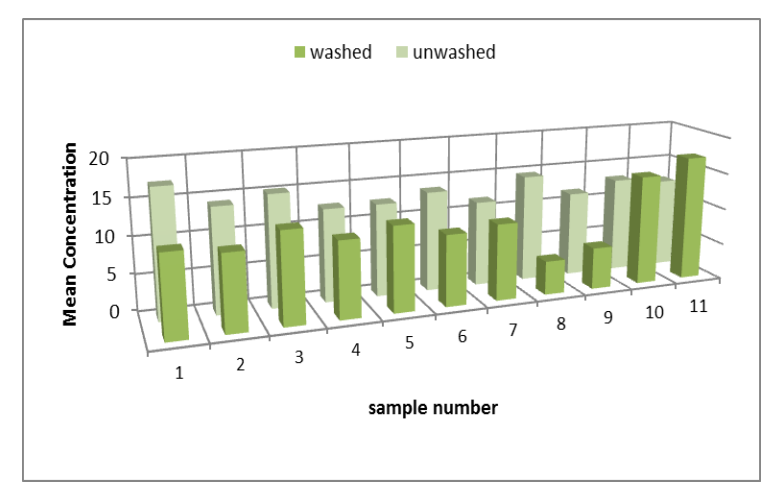

Fig. 7 Mean concentrations for vanadium in washed and unwashed date samples

\section{CONCLUSION}

The measurement of the concentration of some trace elements such as lead, mercury, in soil and crops is of great importance to know the extent of environmental pollution in those areas. There has been high pollution of soil and dates grown in the Zilfi Province elements by lead, but the pollution by mercury is only found in dates samples. Thus can be made for subsequent studies to determine the causes of this pollution.

\section{ACKNOWLEDGMENTS}

The author gratefully thanks Majmmah University for their financial support. The author also would like to thank Deanship of Scientific Research at Majmaah University for supporting this work under Project No.7. Also, express gratitude to Mr. Kamal O.Ahmed at King Saud University for providing the support to complete this work.

\section{REFERENCES}

Abollino O.Aceto M., Malandrino M., Mentasti E., Sarzanini C.and, Petrella F. (2002). Heavy Metals in Agricultural Soils from Piedmont, Italy. Distribution, Speciation and Chemometric data Treatment. Chemosphere 49, 545-557.

Abu-Rekab Z. A., and El-Kerdany A.Y. (2009). Evaluation of Sewy Date palm Cultivar Irrigated by both Treated waste Water and Nile Water. 4th Conference on Recent Technologies in Agriculture, 670-683. 
Ahmed Y., and Ahmed S. (2004) Mineral Ion Content of the Seeds of Six Cultivars of Bahraini Date Palm (Phoenix dactylifera)., J.Agric. Food. Chem. 52,6522-6525.

Aleksand D. (2008). The Impact of Nickel on Human Health. H. J. Elementol., 13(4), 685-696.

Al-Gboori B., and Krepl V. (2010). Importance of Dates Palms as a Source of Nutrition. Agricultura Tropica Et Subtropica, 43 (4),341-347.

Alina K. (2011). Trace elements in soils and plants. 4th ed.p. cm.Includes bibliographical references and index.ISBN 978-1-4200-9368-1 (hardback) pp, 173 .

Al-shahib W., and Marshal R. ( 2003 ). The fruit of the date palm: its possible use as the best food for the future. Int. J. Food Sci. Nutr.54(4),247-259.

Arora M., Bala R., Shweta R., Anchal R., Barinder K., and Neeraj M. (2008). Heavy metal accumulation in vegetables irrigated with water from different sources. Food Chem., 111,811-815.

Babiker M., Rashid A., Aziz A., Heikal M., Yusup S., and Abakar M. (2013). Pyrolysis Characteristics of Phoenix Dactylifera Date Palm Seeds Using Thermo-Gravimetric Analysis (TGA). Intern. J. of Environ. Sci. and Devel., 4(5), 521524.

Ataabadi M.and Najafi P. (2012). Assessment of washing procedure for determination some of the airborne metal concentrations. Afr. J. of Biotech. 11(19), 4391-4395.

Chiroma T., Ebewele R.andHymore F. (2014). Comparative Assessment of Heavy Metals Levels in Soils, Vegetables and Urban Grey Waste Water Used for Irrigation inYola and Kano.Int. Ref. J. of Eng.and Sci(IRJES),3(2), 1-9.

Chojnacha K., Chojnacki H., Gorecka H., and Gorecki H. (2005). Bioavailability of heavy metals from polluted soils to plants. Sci. Total Environ., $333,175-182$.

Chen Y., Wang C., and Wang Z. (2005). Residues and source identification of persistent organic pollutants in farmland soils irrigated by effluents from biological treatment plants. Environ. Intern., 31,77-783.
Halim A. (2013). Heavy Metals in Vegetables Irrigated with Waste Waters in Gazianep, Turkey: A Review of Causes and Potential for Human Health Risks. Fresenius Environmental Bulletin,22(1),146-151.

Jassir M., Shaker A. and Khaliq M. (2005). Deposition of heavy metals on green leafy vegetables sold on roadsides of Riyadh city, Saudi Arabia. Bull. Environ. Contam. Toxico., 75,10201027.

Jorhem L., and Sundstroem B. (1993). Levels of lead, cadmium, zinc, copper, nickel, chromium, manganese and cobalt in foods on the Swedish market, 1983-1990. J. Food Comp. Anal. 6,223241.

Kelepertziz E. (2014) Accumulation of Heavy Metals in Agricultural Soils from Argolida Basin, Peloponnese Greece.Geoderma 221-222,82-90

Khairia T., Zalifah M., Yin Y., and. Aminah A(2004). The uptake of heavy metals by fruit type vegetables grown in selected agricultural areas. Pak. J. Biol. Sci., 7,1438-1442.

Marzouk H.and Kassem H. (2011). Improving fruit quality, nutritional value, and yield of Zaghloul dates by the application of organic and/or mineral fertilizers. Scientia Horticulturae 127, 24.

Mico C., Peris J., Sánchez J., and Recatalá L. (2006). The heavy metal content of agricultural soils in a Mediterranean semiarid area: the Segura River Valley (Alicante, Spain).Spanish Journal of Agricultural Research 4(4) 363-372.

Milacic R., and Kralj B. (2003). Determination of $\mathrm{Zn}, \mathrm{Cu}, \mathrm{Cd}, \mathrm{Pb}, \mathrm{Ni}$ and $\mathrm{Cr}$ in some Slovenian Food stuff. Euro. Food Res. Technol., 217,211214.

Mohammadzai I., Shah Z, Khan H., and Khan S. (2010). Mineral Composition of Date. Palm Fruit and Pit by Atomic Absorption Spectrophotometry. J.Chem.Soc Pak., 32(1), 8790.

Mohebi A. (2010). Growth And Heavy Metals Uptake By Date palm Grown in Mono-And Dual Culture In Heavy Metals contaminated Soil. Wor. Appl. Sci. J. 15 (3), 429-435. 
Mohsen and Mohsen (2013).Investigation of metals accumulation in some vegetables irrigated with wastewater in Shahre Rey-Iran and toxicological implications. American-Eurasian J. of Agric. and Environ.SCI.,4(1):86-92.

Muchuweti M., Birkett J., Chinyanga E., Zvauya R., Scrimshah M., and Lester J. (2006). The heavy metal content of vegetables irrigated with a mixture of wastewater and sewage sludge in Zimbabwe, implications for human health. Agri. Ecosys. Environ., 1129, 41-48.

Mumzuroglu O., Karatas F., and Geckil H. (2003). The vitamin and selenium contents of apricot fruit of different varieties cultivated in different geographical regions. Food Chem. $83,205-212$.

Naveed N., Batool A., Rehman F. and Hameed U. (2010). Leaves of roadside plants as a bioindicator of traffic-related lead pollution during different seasons in Sargodha, Pakistan. Afri. J. of Envir. Sci. and Techn. 4(11),770-774).

Nedelescu M., Balalu C., Baconi D., Jula M., Morar D.and Gligor A. (2015). Preliminary assessment of heavy metals content of vegetables grown in industrial areas in Romania.Farmacia,63(2) 296-300.

Ogbonnaa P., Odukaesiemea C., and Silvab J. (2013). Distribution of heavy metals in soil and accumulation in plants at an agricultural area of Umudike, Nigeria. Chem. and Ecol.,29( 7), 595603.

Ogunkunle A., Bello O.and Ojofeitimi O. (2014). Determination of Heavy Metal Contamination of Street-Vended Fruits and vegetables in Lagos State, Nigeria. Intrer. Food Res. J. 21(5), 17251730.

Rahman S., Khanam D., Adyel T., Islam M., Ahsan M.and Akbor M. (2012). Assessment of Heavy Metal Contamination of Agricultural Soil around Dhaka Export Processing Zone (DEPZ), Bangladesh: Implication of Seasonal Variation and Indices, Appl. Sci., 2,584-601.

Raikwar M., Kumar P., Singh M.and Singh A. (2008).Toxic effect of heavy metals in lifestock health. Veterinary World.1(1), 28-30.
Saracoglu S., Tuzen D., Mendil M., Soylak L.,

Elci L., and Dogan M. (2004). The heavy metal content of hard biscuits produced in Turkey. Bull. Environ. Contam. Toxicol., 73,264-269.

Singh K., Mohan D., Sinha S., and Dalwani R. (2004). Impact assessment of treated/untreated wastewater toxicants discharged by sewage treatment plants on health, agricultural and environmental quality in the wastewater disposal areas. Chemosphere, 55,227-255.

Simona D., Adriana C., Maximiliana C., Manfred A. and vanadium A. (2009). In Medicinal Plants: New Data On The Occurence Of An Element Both Essential And Toxic To Plants And Man. Analele Universitii din Oradea, Fascicula Biologie, Tom. XVI / 2, pp. 5-10.

Szydłowska-Czerniak A., Trokowski K., Karlovits G.and Szlyk E. (2013). Spectroscopic Determination of Metals in Palm Oils from Different Stages of the Technological Process. J. Agric. Food Chem., 61 (9) 2276-2283.

Trabzuni D., Ahmed S., and Abu-Tarboush H. (2014) Food and Nutrition Sciences, 5,13791386.

Tuzen M. (2003).Determination of Heavy Metals in Fish samples of the Middame Lakes Black Sea (Turkey ) by Graphite Furnace Atomic Absorption Spectrophotometry. Food Chem.,80,119-113.

Williams J. and Pillay E. (2011). Metals, Metalloids, and Toxicity in Date Palms: Potential Environmental Impact. J. of Envi.1 Pro., 2, 592600.

Yassine El., Sophie D., Mejdi J., Gwénaelle T.and Rachid S.(2012). Measurement of Gaseous and Particulate Pollutants during Combustion of Date Palm Wastes for Energy Recovery. Aerosol and Air Quality Research, 12, 814-825.

Uddin A. J. (2010). Heavy metal contamination in water, soil, and vegetables of the industrial areas in Dhaka, Bangladesh. Environ Monit Assess. 166,347-357. 
$++\mathrm{UnW}^{*}=$ unwashed date sample $\mathrm{W}^{* *}=$ washed date sample

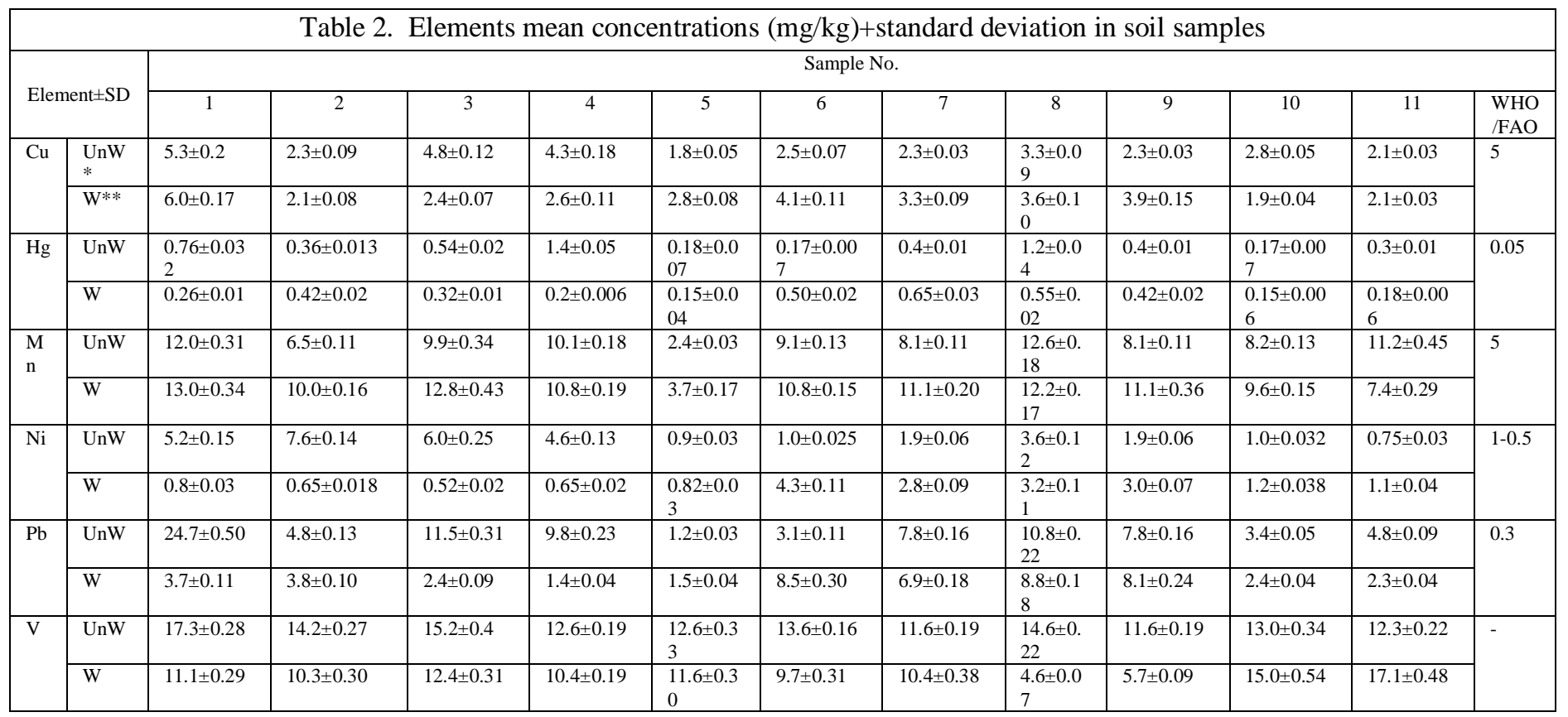

Table 3. Elements mean concentrations $(\mathrm{mg} / \mathrm{kg})+$ standard deviation in unwashed and washed dates samples

\begin{tabular}{|c|c|c|c|c|c|c|c|c|c|c|c|c|}
\hline \multirow{2}{*}{$\begin{array}{c}\text { Element } \pm \\
\text { SD }\end{array}$} & \multicolumn{12}{|c|}{ Sample No. } \\
\hline & 1 & 2 & 3 & 4 & 5 & 6 & 7 & 8 & 9 & 10 & 11 & WHO \\
\hline $\mathrm{Cu}$ & $\begin{array}{c}16.9 \pm 0 . \\
4\end{array}$ & $\begin{array}{c}8.8 \pm 0.3 \\
3 \\
\end{array}$ & $5.8 \pm 0.15$ & $\begin{array}{c}14.3 \pm 0 . \\
46\end{array}$ & $\begin{array}{c}15.6 \pm 0.4 \\
4\end{array}$ & $\begin{array}{c}14.5 \pm 0 . \\
46\end{array}$ & $6.3 \pm 0.16$ & $9.3 \pm 0.38$ & $8.1 \pm 0.23$ & $13.6 \pm 0.52$ & $16.6 \pm 0.63$ & 100 \\
\hline $\mathrm{Hg}$ & $\begin{array}{c}1.5 \pm 0.0 \\
4\end{array}$ & $\begin{array}{c}1.5 \pm 0.0 \\
5\end{array}$ & $1.9 \pm 0.07$ & $\begin{array}{c}1.4 \pm 0.0 \\
5\end{array}$ & $2.8 \pm 0.11$ & $2.6 \pm 0.1$ & $1.5 \pm 0.06$ & $2.3 \pm 0.08$ & $2.3 \pm 0.08$ & $2.9 \pm 0.12$ & $3.0 \pm 0.1$ & 5 \\
\hline $\mathrm{Mn}$ & $\begin{array}{c}106.9 \pm \\
2.8\end{array}$ & $\begin{array}{c}123.8 \pm \\
1.98 \\
\end{array}$ & $55.9 \pm 1.0$ & $\begin{array}{c}506.9 \pm \\
5.6\end{array}$ & $\begin{array}{c}110.3 \pm 2 . \\
76\end{array}$ & $\begin{array}{c}462.1 \pm 8 \\
.3\end{array}$ & $\begin{array}{c}241.4 \pm 3 . \\
38\end{array}$ & $\begin{array}{c}96.9 \pm 1.7 \\
4\end{array}$ & $212.8 \pm 2.98$ & $249.2 \pm 2.74$ & $247.0 \pm 6.67$ & 2000 \\
\hline $\mathrm{Ni}$ & $\begin{array}{c}26.0 \pm 0 . \\
6 \\
\end{array}$ & $\begin{array}{c}15.5 \pm 0 . \\
28\end{array}$ & $\begin{array}{l}12.0 \pm 0.2 \\
4\end{array}$ & $\begin{array}{c}48.1 \pm 0 . \\
9\end{array}$ & $\begin{array}{c}17.4 \pm 0.5 \\
6 \\
\end{array}$ & $\begin{array}{c}23.0 \pm 0 . \\
62 \\
\end{array}$ & $3.6 \pm 0.09$ & $\begin{array}{c}14.8 \pm 0.4 \\
3 \\
\end{array}$ & $8.9 \pm 0.3$ & $12.2 \pm 0.39$ & $19.4 \pm 0.58$ & 50 \\
\hline $\mathrm{Pb}$ & $\begin{array}{c}79.0 \pm 2 . \\
4\end{array}$ & $\begin{array}{c}42.2 \pm 1 \\
14\end{array}$ & $7.2 \pm 0.16$ & $\begin{array}{c}20.4 \pm 0 . \\
5\end{array}$ & $\begin{array}{c}184.4 \pm 3 \\
32\end{array}$ & $\begin{array}{c}182.6 \pm 3 \\
.65\end{array}$ & $\begin{array}{c}92.4 \pm 2.7 \\
7 \\
\end{array}$ & $\begin{array}{c}81.8 \pm 1.8 \\
8\end{array}$ & $59.9 \pm 1.2$ & $154.0 \pm 3.39$ & $131.1 \pm 1.57$ & 100 \\
\hline V & $\begin{array}{c}79.3 \pm 1 . \\
6\end{array}$ & $\begin{array}{c}90.6 \pm 1 . \\
36\end{array}$ & $91.9 \pm 2.3$ & $\begin{array}{c}82.6 \pm 1 . \\
4\end{array}$ & $\begin{array}{c}136.5 \pm 3 . \\
0\end{array}$ & $\begin{array}{c}131.6 \pm 1 \\
.97\end{array}$ & $\begin{array}{c}84.8 \pm 1.0 \\
2\end{array}$ & $\begin{array}{c}112.8 \pm 1 . \\
69\end{array}$ & $114.4 \pm 1.83$ & $110.0 \pm 2.86$ & $100.2 \pm 1.5$ & - \\
\hline
\end{tabular}

